\title{
Suplementasi Tempe Meningkatkan Status Besi dan Perkembangan Anak
}

Lidya Diah Wulandari Sidharta, JC Susanto

Bagian/SMF Ilmu Kesehatan Anak Fakultas Kedokteran Universitas Diponegoro/RSUP Dr. Kariadi, Semarang

Latar belakang. Anemia defisiensi besi dapat menyebabkan dampak negatif pada kesehatan terutama anak-anak, baik menurunkan daya tahan tubuh maupun mengganggu konsentrasi belajar dan perkembangan anak.

Tujuan. Mengetahui manfaat pemberian tempe yang diberikan bersamaan makan pada anak terhadap peningkatan kadar hemoglobin, kadar serum iron, feritin, status antropometri, dan perkembangan pada anak.

Metode. Penelitian one group pre and post test design dilakukan di daerah Bululor Semarang pada 30 anak usia 12 -18 bulan yang memenuhi kriteria inklusi, diberikan tempe goreng 25 gram tiga kali sehari bersamaan makan selama 6 bulan. Sebelum dan setelah perlakuan dilakukan pengukuran antropometri berupa WAZ, HAZ, WHZ, dan pemeriksaan laboratorium kadar hemoglobin, serum iron, feritin, serta pemeriksaan perkembangan dengan tes Bayley berupa mental developmental index (MDI) dan psychomotor developmental index (PDI). Analisis statistik menggunakan Paired t test dan uji t tidak berpasangan bila sebaran data normal, Wilcoxon test dan Mann Whitney bila sebaran data tidak normal.

Hasil. Terjadi kenaikan status antropometri (WAZ, HAZ, WHZ), status besi (serum besi, feritin) dan status perkembangan (MDI, PDI) yang bermakna secara statistik $(\mathrm{p}<0,05)$, walaupun didapatkan juga peningkatan kadar hemoglobin yang tidak bermakna secara statistik $(\mathrm{p}=0,057)$ dengan rerata delta kenaikan hemoglobin sebesar $0,2 \pm 0,55 \mathrm{gr} / \mathrm{dL}$.

Kesimpulan. Pemberian tempe pada anak usia 12-18 bulan saat makan selama enam bulan dapat meningkatkan kenaikan kadar hemoglobin, serum besi, feritin, WAZ, HAZ, WHZ, dan MDI, PDI. Sari Pediatri 2016;18(3):169-74

Kata kunci: anemia defisiensi besi, tempe, kadar hemoglobin, serum besi, feritin, MDI, PDI

\section{Tempeh Supplementation Increase Iron Status and Children Development}

Lidya Diah Wulandari Sidharta, JC Susanto

Background. Iron deficiency anemia could impact children's health which leads to immunity impairment, lack of concentration in school and their development.

Objective. To define the benefit of tempeh supplementation at meal times on to increase haemoglobin, serum iron, feritin, anthropometric status and development.

Method. This was a one group pre and post test study held in Bululor Semarang area. Thirty children aged $12-18$ months who met the inclusion criteria were given 25 grams of fried tempeh at meal time three times daily for 6 months. Before and after the suplementation, WAZ, HAZ, WHZ, haemoglobin, iron serum, feritin, and also development test with Bayley's test which consist of Mental Developmental Index (MDI) and Psychomotor Developmental Index (PDI) are measured. We used paired test and independent test for normally distributed data, Wilcoxon test dan Mann Whitney for abnormal distributed data for statistic analysis. Result. There is an increase of anthropometric status (WAZ, HAZ, WHZ), iron status (serum iron, ferritin) and development status (MDI, PDI), which was statistically significant $(\mathrm{p}<0.05)$, although we also found increased haemoglobin level which is not significant $(\mathrm{p}=0.057)$, with a mean increase delta of $0.2 \pm 0.55 \mathrm{~g} / \mathrm{dl}$.

Conclusion. Six month tempeh supplementation at meal times for children 12-18 months old could increase haemoglobin, iron serum, feritin, WAZ, HAZ, WHZ, MDI and PDI. Sari Pediatri 2016;18(3):169-74

Keywords: iron deficiency anemia, tempeh, haemoglobin, iron serum, feritin, WHZ, MDI and PDI

Alamat korespondensi: Dr. Lidya Diah Wulandari Sidharta, Dr. JC Susanto, SpA(K). Bagian/SMF Ilmu Kesehatan Anak Fakultas Kedokteran Universitas Diponegoro/ RSUP Dr. Kariadi, Semarang. Email: adeyusma@idola.net.id 
$\mathrm{P}$ revalensi anemia defisiensi besi pada anak di dunia masih tinggi. World Health Organization memperkirakan $27 \%{ }^{1}$ dan menurut SKRT 2007 prevalensi anemia pada anak usia 1-4 tahun di Indonesia sekitar 27,7\%. ${ }^{2}$ Jika anemia defisiensi besi atau defisiensi besi terjadi pada awal kehidupan maka dapat mengganggu perkembangan anak. ${ }^{3}$ Anemia defisiensi besi yang terjadi pada saat bayi dapat menyebabkan terjadinya hambatan perkembangan saat usia 8 sampai 9 tahun, meskipun telah dilakukan terapi besi. Temuan ini konsisten dengan dampak jangka panjang anemia defisiensi besi yang terjadi saat awal mielinasi dan saat pembentukan jaringan neurologis prefrontal striatal. ${ }^{4}$ Pengamatan perkembangan kognitif baru dapat dilakukan setelah anak berumur 6 bulan karena anemia defisiensi besi biasanya mulai muncul disaat anak berusia 6-12 bulan. Saat usia inilah cadangan besi saat anak lahir sudah mulai menipis, sedangkan asupan diet anak kurang mengandung zat besi, masa "weaning period" ini biasa disebut critical period."

Zat besi dalam makanan dapat berupa besi heme maupun besi non heme. Besi heme ini walaupun jumlahnya sedikit, tetapi mempunyai nilai biovailabilitas tinggi. Sementara besi non heme absorpsinya tergantung pada makanan lainnya yang dikonsumsi secara bersamaan. Terdapat makanan yang dapat meningkatkan penyerapan zat besi, seperti vitamin $\mathrm{C}$ dan pemberian daging merah. Sementara pemberian asam fitat, fiber, polifenol, tanin dapat menghambat penyerapan zat besi. Asam fitat banyak terdapat pada makanan utama seperti sereal. Pengurangan kadar asam fitat memerlukan enzim fitase yang dapat memecah asam fitat sehingga penyerapan zat besi tidak terhambat. Makanan yang mengandung enzim fitase salah satunya adalah tempe. Tempe merupakan makanan asli Indonesia yang berasal dari kedelai. Konsumsi tempe diharapkan dapat mengurangi faktor penghambat penyerapan zat besi, yaitu asam fitat sehingga penyerapan zat besi meningkat. ${ }^{5}$ Defisiensi besi akan memperlihatkan adanya gangguan pembentukan pada struktur dendritik di daerah hippocampus. ${ }^{6}$

Terapi besi oral pada anak dengan anemia kekurangan zat besi saat usia 6,12 atau 18 bulan dilakukan di Cili. Setelah dilakukan pengamatan dan penilaian potensi perkembangan memori dan fungsi dari hippocampus saat mereka usia 4 dan 10 tahun, ditemukan anemia defisiensi besi yang terjadi pada awal kehidupan dan terbukti menurunkan metabolisme saraf dan menurunkan proses neurotransmisi. Hal tersebut tidak dapat diperbaiki 4 tahun kemudian meskipun telah dilakukan pengobatan. ${ }^{7}$

Penelitian Cercamondi ${ }^{8}$ di Natitingou, Benin, dengan subyek enam puluh anak sehat dengan usia 19-36 bulan secara randomized cross over study, penambahan fitase aktif, asam askorbat dan EDTA pada MP-ASI terbukti dapat meningkatkan penyerapan besi. Troesch ${ }^{9}$ menyatakan peningkatan absorbsi besi lima kali dengan penambahan vitamin C, fitase pada makanan.

Penelitian bertujuan untuk mengetahui pengaruh asupan tempe (fitase) terhadap peningkatan status besi, perubahan status antropometri dan perkembangan pada anak usia 12 - 18 bulan.

\section{Metode}

Penelitian rancangan pre and post test one group only dengan lingkup Ilmu Kesehatan Anak Divisi Nutrisi dan Penyakit Metabolik. Penelitian dilaksanakan selama 6 bulan setelah mendapat persetujuan dari komisi etik FK UNDIP/ RS dr Kariadi Semarang. Penelitian berlangsung di daerah Bulu Lor Semarang pada anak usia 12-18 bulan yang datang ke Posyandu.

Kriteria inklusi adalah anak sehat usia 1218 bulan, bertempat tinggal di daerah Bulu Lor Semarang, orang tua atau wali bersedia menjadi subyek penelitian (mengisi informed consent), orang tua bersedia memberikan tempe setiap kali anak makan selama 6 bulan dan mengisi buku harian. Kriteria eksklusi adalah anak yang mendapatkan suplementasi besi sebelum penelitian, riwayat penyakit kronis (lebih dari 3 bulan).

Subyek penelitian dipilih dengan cara concecutive sampling. Sesuai dengan hipotesis penelitian, besar sampel dihitung dengan rumus untuk uji hipotesis. Jika ditentukan $(Z \alpha=1,96)$, kekuatan penelitian sebesar $90 \%(Z \beta=1,44)$. Berdasarkan penelitian sebelumnya, simpang baku kadar hemoglobin pada anak dengan pemberian fitase sebesar $8 \mathrm{mg} / \mathrm{dL} .{ }^{8}$ Perbedaan sebesar 5 mg/dL dianggap bermakna. ${ }^{10}$ Berdasarkan perhitungan di atas, besarnya sampel yang dibutuhkan minimal 27 anak. Dengan koreksi terhadap kemungkinan drop out 10\% maka subyek yang diperlukan 30 anak.

Subyek diberi perlakuan berupa pemberian tempe 25 gram dengan ukuran $4 \mathrm{~cm} \times 4 \mathrm{~cm} \times 2 \mathrm{~cm}$ sehari 
Lidya Diah Wulandari Sidharta dkk: Suplementasi tempe meningkatkan status besi dan perkembangan anak

3 kali, selama 6 bulan. Semua subyek pada awal penelitian diukur berat badan, tinggi badan oleh tenaga kesehatan yang terlatih dan berpengalaman kemudian dinilai WHZ. Serta dilakukan pemeriksaan laboratorium kadar hemoglobin, serum iron, kadar serum feritin, pemeriksaan perkembangan dengan menggunakan perhitungan indeks perkembangan mental MDI dan indeks perkembangan psikomotorik uji PDI Bayley saat awal dan akhir penelitian. Setiap bulan dilakukan pengukuran antropometri, dilakukan evaluasi pencatatan food recall. Untuk mengetahui pengaruh pemberian tempe terhadap kadar hemoglobin, serum besi, feritin, WHZ, MDI, dan PDI dilakukan analisis data secara statistik paired t test jika distribusi data normal atau Wilcoxon test jika distribusi data tidak normal. Nilai p dianggap bermakna apabila $\mathrm{p}<0,05$. Etika penelitian ini dimintakan ethical clearance dari Komisi Etik Penelitian Kedokteran UNDIP/RSDK. Persetujuan orang tua atau wali diberikan secara tertulis dalam bentuk informed consent.

\section{Hasil}

Penelitian dilakukan pada bulan Juli 2015 - Januari 2016, di Posyandu Bulu Lor Semarang. Pada seluruh subyek penelitian, sejak anamnesis tidak didapatkan adanya penyakit diare kronis. Karakteristik subyek tertera pada Tabel 1 dengan sebagian besar subyek berusia 12 bulan dan 18 anak berjenis kelamin lakilaki.

Tabel 2 menunjukkan pencatatan rerata konsumsi tempe harian anak selama 6 bulan, rerata konsumsi harian tempe tercapai tertinggi 66,77 gram dan terendah 58,87 gram per hari dari yang seharusnya dikonsumsi sebanyak 75 gram per hari. Tidak didapatkan adanya perbedaan yang bermakna $(\mathrm{p}=0,057)$ antara kadar hemoglobin sebelum dan sesudah pemberian tempe, meskipun diperoleh kenaikan rerata kadar hemoglobin dari $(0,20 \pm 0,50)$ gram sesudah pemberian tempe. Terdapat peningkatan kadar hemoglobin $(0,2 \pm 0,05)$ gram setelah pemberian tempe, meskipun tidak bermakna secara statistik ( $\mathrm{p}=0,057)$, kemungkinan terjadi karena jumlah sampel yang kecil.

Pemberian tempe meningkatkan kadar serum besi, feritin $(\mathrm{p}<0,05)$, dengan kenaikan median kadar serum besi (30), median feritin $(0,6)$ setelah pemberian tempe (Tabel 3). Demikian juga dengan peningkatan rerata
Tabel 1. Karakteristik subyek penelitian $(\mathrm{n}=30)$

\begin{tabular}{lcc}
\hline Variabel & frekuensi & Mean \pm SD \\
\hline Usia (bulan, \%) & & $12,50 \pm 0,68$ \\
12 & $18(60)$ & \\
13 & $9(30)$ & \\
14 & $3(10)$ & \\
Jenis kelamin,(\%) & & \\
Laki-laki & $18(60)$ & \\
Perempuan & $12(40)$ & \\
BB awal & & $7,98 \pm 059$ \\
TB awal & & $-0,61 \pm 0,48$ \\
WAZ awal & & $0,47 \pm 0,70$ \\
HAZ awal & & $-1,09 \pm 0,62$ \\
WHZ awal & \multicolumn{2}{c}{ BB : berat badan TB : tinggi badan WHZ : weight for height } \\
score WAZ : weight for age HAZ : height for age
\end{tabular}

Tabel 2. Rerata konsumsi tempe dalam gram per hari

\begin{tabular}{lcc}
\hline Bulan & Mean \pm SD (gram) & Median (Min-mak) \\
\hline 1 & $66,77 \pm 8,6$ & $70(50-75)$ \\
2 & $59,27 \pm 8,9$ & $57,5(50-75)$ \\
3 & $58,87 \pm 10,0$ & $55(50-75)$ \\
4 & $59,57 \pm 8,2$ & $61(50-75)$ \\
5 & $59,3 \pm 8,2$ & $60(50-75)$ \\
6 & $61,2 \pm 10,5$ & $58,5(50-75)$ \\
\hline
\end{tabular}

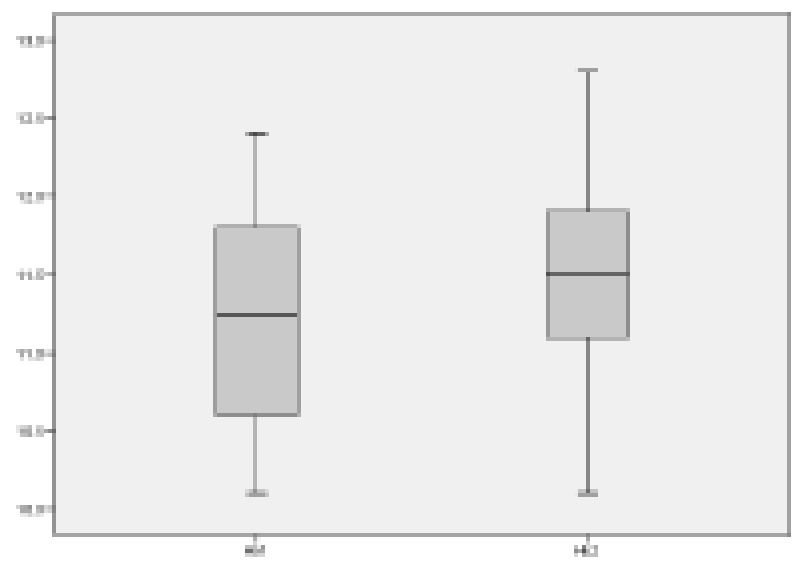

Gambar 1. Pola kadar hemoglobin pada anak sebelum dan sesudah pemberian tempe 
Lidya Diah Wulandari Sidharta dkk: Suplementasi tempe meningkatkan status besi dan perkembangan anak

Tabel 3. Pengaruh pemberian tempe $\mathrm{n}=30$

\begin{tabular}{|c|c|c|c|c|c|}
\hline \multirow[t]{2}{*}{ Variabel } & \multicolumn{2}{|c|}{ Rerata \pm SD } & \multicolumn{2}{|c|}{ Median (min-maks) } & \multirow[t]{2}{*}{$\mathrm{p}$} \\
\hline & Awal & Akhir & Awal & Akhir & \\
\hline Hemoglobin (gram) & $11,24 \pm 0,74$ & $11,44 \pm 0,69$ & $11,25(10,1-12,4)$ & $11,5(10,1-12,8)$ & $0,057^{a}$ \\
\hline Serum besi (gram) & $39,33 \pm 16,24$ & $55,5 \pm 21,85$ & $36(14-67)$ & $66(14-89)$ & $0,0001^{\mathrm{b}}$ \\
\hline Feritin (gram) & $38,26 \pm 23,19$ & $31,14 \pm 20,25$ & $40,75(5,6-98,7)$ & $32,25(5,6-79,1)$ & $0,031^{\mathrm{b}}$ \\
\hline $\mathrm{BB}(\mathrm{kg})$ & $8,98 \pm 0,59$ & $10,77 \pm 0,93$ & $8,95(8,00-10,2)$ & $10,9(8,40-12,8)$ & $0,005^{\mathrm{a}}$ \\
\hline TB $(\mathrm{cm})$ & $77,59 \pm 1,79$ & $80,7 \pm 2,05$ & $77,85(73-80,3)$ & $80,55(73,5-85,5)$ & $<0,001^{\mathrm{a}}$ \\
\hline WAZ & $-0,61 \pm 0,48$ & $-0,11 \pm 0,77$ & $-0,66(-1,45-0,4)$ & $-0,0(-1,79-1,37)$ & $<0,001^{\mathrm{ab}}$ \\
\hline HAZ & $0,47 \pm 0,70$ & $-0,76 \pm 0,59$ & $0,52(-1,6-1,76)$ & $-0,82(-2,59-0,63)$ & $<0,001^{\mathrm{ab}}$ \\
\hline WHZ & $-1,09 \pm 0,62$ & $0,34 \pm 0,74$ & $-1,15(-1,94-0,42)$ & $0,51(-1,52-1,47)$ & $0,0001^{\mathrm{a}}$ \\
\hline MDI & $88,2 \pm 14,26$ & $94,67 \pm 12,37$ & $86,50(63-110)$ & $91,50(70-112)$ & $0,0001^{a}$ \\
\hline PDI & $90,57 \pm 17,98$ & $97,1 \pm 16,27$ & $92(56-113)$ & $97(67-121)$ & $0,0001^{a}$ \\
\hline
\end{tabular}

${ }^{\mathrm{a}}$ Paired t test ${ }^{\mathrm{b}}$ Wilcoxon test $\mathrm{BB}:$ berat badan $\mathrm{TB}:$ tinggi badan $\mathrm{WHZ}:$ weight for height score WAZ : weight for age

HAZ : height for age MDI : mental development index PDI : psychomotor development index

Tabel 4. Uji beda berpasangan pada anak ASI dan susu formula sebelum dan sesudah pemberian tempe

\begin{tabular}{lcccccc}
\hline \multirow{2}{*}{ Variabel (gram) } & \multicolumn{5}{c}{ ASI } & \multicolumn{4}{c}{ Susu formula } \\
\cline { 2 - 7 } & Awal & Akhir & $\mathrm{p}$ & Awal & Akhir & $\mathrm{p}$ \\
\hline Kalori & $815,1(780,5-895)$ & $929,15(820,3-1076,5)$ & $0,005^{*_{2}}$ & $1255,3(876-1765)$ & $1494,9(1028,4-1993)$ & $<0,001^{* a}$ \\
Karbohidrat & $101,9(87,9-141,1)$ & $112,5(104,1-152,3)$ & $0,005^{*_{2}}$ & $178,4(102,3-204,3)$ & $196,95(123,3-224,7)$ & $<0,001^{*_{a}}$ \\
Protein & $31,97 \pm 8,5$ & $41,15 \pm 5,09$ & $0,005^{*_{a}}$ & $68,46 \pm 23,38$ & $79,41 \pm 22,34$ & $<0,001^{* d}$ \\
Lemak & $36,65(30-56,7)$ & $42,7(39,5-62)$ & $0,005^{* a}$ & $58,2(34,4-90,5)$ & $66,7(42-92,5)$ & $<0,001^{*_{a}}$ \\
Besi & $14,64 \pm 7,63$ & $16,97 \pm 8,19$ & $<0,001^{* d}$ & $31,5 \pm 8,25$ & $34,53 \pm 7,8$ & $<0,001^{* d}$ \\
\hline
\end{tabular}

Keterangan : ${ }^{*}$ Signifikan $\mathrm{p}<0,05 ;{ }^{\mathrm{a}} \mathrm{Uji}$ Wilcoxon; ${ }^{\mathrm{d}} \mathrm{Uji}$ t berpasangan

Tabel 5. Uji beda tidak berpasangan pada anak ASI dan susu formula sebelum dan sesudah pemberian tempe

\begin{tabular}{lcccccc}
\hline Variabel & \multicolumn{7}{c}{ Awal } & \multicolumn{3}{c}{ Akhir } \\
\cline { 2 - 7 } & ASI & Susu formula & $\mathrm{p}$ & ASI & Susu formula & $\mathrm{p}$ \\
\hline Kalori & $815,1(780,5-895)$ & $1255,3(876-1765)$ & $<0,001^{* \mathrm{~b}}$ & $929,15(820,3-1076,5)$ & $1494,9(1028,4-1993)$ & $<0,001^{* \mathrm{~b}}$ \\
Karbohidrat & $101,9(87,9-141,1)$ & $178,4(102,3-204,3)$ & $<0,001^{* \mathrm{c}}$ & $112,5(104,1-152,3)$ & $196,95(123,3-224,7)$ & $<0,001^{* \mathrm{c}}$ \\
Protein & $31,97 \pm 8,5$ & $68,46 \pm 23,38$ & $<0,001^{* \mathrm{c}}$ & $41,15 \pm 5,09$ & $79,41 \pm 22,34$ & $<0,001^{* \mathrm{~b}}$ \\
Lemak & $36,65(30-56,7)$ & $58,2(34,4-90,5)$ & $<0,001^{* \mathrm{~b}}$ & $42,7(39,5-62)$ & $66,7(42-92,5)$ & $<0,001^{* \mathrm{~b}}$ \\
Besi & $14,64 \pm 7,63$ & $31,5 \pm 8,25$ & $<0,001^{* \mathrm{~b}}$ & $16,97 \pm 8,19$ & $34,53 \pm 7,8$ & $<0,001^{* \mathrm{~b}}$ \\
\hline
\end{tabular}

Keterangan : * Signifikan p $<0,05 ;{ }^{\mathrm{b}}$ Uji Mann Whitney; ${ }^{\mathrm{c}}$ Uji t tidak berpasangan

WAZ,HAZ,WHZ, MDI, PDI yang bermakna secara stastistik dengan pemberian tempe $(\mathrm{p}<0,05)$.

Pada Tabel 4 dan 5 didapatkan perbedaan bermakna antara asupan kalori, karbohidrat, protein, lemak, besi sebelum dan sesudah pemberian tempe baik pada subyek yang mendapatkan ASI maupun susu formula $(\mathrm{p}<0,05)$.

\section{Pembahasan}

Hubungan antara penurunan kandungan asam fitat dan peningkatan waktu fermentasi dapat dijelaskan karena sintesis enzim fitase terjadi hidrolisis asam fitat. Penurunan polifenol menunjukkan kemampuan flora mikro untuk fermentasi fenolat. ${ }^{11}$ Kami mendapatkan 
hasil perbedaan pada pemberian tempe terhadap kadar serum besi anak, sebelum diberi tempe 36 gram, naik menjadi 66 gram setelah diberi tempe.

Pemberian asam askorbat (vitamin C) dan fitase (190 fitase unit), NaFeEDTA dapat meningkatkan absorbsi besi lima kali bila dibandingkan absorbsi besi pada makanan yang sama tanpa dilakukan penambahan. ${ }^{12}$ Hal tersebut sesuai dengan hasil pada penelitian kami, yaitu peningkatan kadar serum feritin berbeda sebelum dan sesudah perlakuan. Hal ini menunjukkan adanya manfaat pemberian tempe yang mengandung fitase pada saat makan.

Kami memperoleh hasil peningkatan HAZ meskipun didapatkan HAZ dari $0,47 \mathrm{SD}$ saat usia 12-18 bulan menjadi -0,76SD saat usia 18-24 bulan. Sesuai dengan penelitian Victoria ${ }^{13}$ yang melaporkan penurunan HAZ saat pengamatan sejak usia 0 bulan dengan HAZ -0,15SD menjadi -1,75SD saat usia 24 bulan.

Asupan kalori, karbohidrat, protein, lemak, besi pada hasil food recall bermakna sebelum dan sesudah pemberian tempe, baik pada anak yang memperoleh ASI maupun susu formula. Rerata lebih tinggi terdapat pada anak dengan susu formula. Terdapat kesulitan menghitung berdasarkan food recall pada anak yang mengonsumsi ASI. Perhitungan jumlah ASI yang diberikan berdasarkan anak menetek langsung bukan menggunakan ASI perah. Lama menetek terkadang ibu tidak menyadari lama pemberian ASI, pencatatan ibu pada food recall. Sementara terdapat beberapa faktor yang dapat juga memengaruhi komposisi ASI, antara lain, usia gestasi, usia pascanatal, stadium penyusuan (pada permulaan atau akhir menyusui), serta frekuensi bayi menyusu. ${ }^{14}$

Pengamatan dan pemantauan ketaatan subyek penelitian untuk mengonsumsi tempe setiap hari selama 6 bulan dilakukan peneliti dengan membuat food recall serta adanya kunjungan rumah baik terjadwal di Posyandu maupun kunjungan rumah secara acak untuk memperoleh data ketaatan subyek maupun orangtua dalam mengikuti penelitian. Pada proses pemantauan ini, peneliti dibantu oleh kader Posyandu yang telah diberitahukan mengenai hal- hal yang dipantau pada subyek penelitian seperti subyek tetap mengkonsumsi tempe yang telah dibagikan sehari tiga kali dan dilakukan pada saat makan bukan sebagai camilan.

Penelitian ini menggunakan pemeriksaan Bayley Infant Scale of Development (BINS), merupakan pemeriksaan baku emas untuk pemeriksaan keterlambatan perkembangan dan masalah perilaku, hanya dapat dilakukan oleh tenaga psikologi terapan yang telah tersertifikasi. Didapatkan peningkatan pada pemberian tempe saat pemberian MP-ASI terhadap perkembangan. Pada skor BINS didapatkan kenaikan rerata skor MDI 6,47 dan PDI 6,53.

Penelitian ini memiliki beberapa keterbatasan. Pertama, fitase yang diberikan dalam bentuk tempe yang sudah dimasak. Fitase dalam bentuk makanan yang siap saji ataupun bentuk suplemen makanan sulit diperoleh sehingga fitase diberikan dalam bentuk tempe. Belum dilakukan pemeriksaan kadar fitase dalam darah karena reagen fitase belum tersedia. Kandungan nutrisi tempe yang dipergunakan tidak dapat dianalisis karena instansi laboratorium tidak dapat melakukan uji zat nutrisi yang terkandung dalam tempe tersebut. Kedua, penelitian kami hanya menggunakan satu kelompok perlakuan tanpa membandingkan dengan kelompok kontrol, serta dilakukan pada satu daerah tertentu saja. Belum dilakukan kontrol terhadap infeksi yang dapat berpengaruh terhadap status gizi, kadar $\mathrm{Hb}$, kadar serum feritin pada penelitian. Ketiga, tidak dilakukan pemeriksaan tinja pada subyek untuk mengetahui adanya infestasi cacing pada subyek. Puskesmas Bulu Lor tidak memiliki data tentang angka kecacingan. Keempat, dalam proses pemantauan ketaatan subyek penelitian kami didapatkan bias informasi karena pengumpulan data konsumsi tempe dilakukan oleh orangtua subyek. Telah dilakukan validasi data dengan menggunakan data pencatatan food recall serta melakukan kunjungan, baik secara kelompok subyek lewat Posyandu maupun kunjungan rumah secara individu, yang dilakukan tidak terjadwal. Saat kunjungan, baik ke Posyandu maupun ke rumah, peneliti melakukan pengamatan mengenai konsumsi tempe yang dibagikan baik cara pemberian yang seharusnya dilakukan bersamaan makan, rata-rata konsumsi tempe sehari 58,87 gram sampai dengan 66,77 gram.

\section{Kesimpulan}

Terdapat peningkatan kadar serum besi dan serum feritin, WAZ, HAZ, WHZ,MDI, PDI pada pemberian tempe saat makan pada anak usia 12-18 bulan. Terdapat peningkatan kadar hemoglobin pada pemberian tempe tetapi tidak bermakna. Sebaiknya 
dilakukan pemberian tempe bersamaan saat anak makan pada anak mulai usia 12 bulan, dapat dilakukan penelitian mengenai pemberian tempe pada anak dengan menggunakan populasi subyek lebih banyak, dilakukan blinding, ada kelompok kontrol sebagai pembanding, serta pada populasi yang lebih homogen dan populasi yang mengalami anemia sebagai subyek penelitian.

\section{Daftar pustaka}

1. Stoltzfus RJ. Iron Interventions for women and children in low-income countries. J Nutr 2011:1S-7S.

2. Riset Kesehatan Dasar (RISKESDAS) 2007 Laporan Nasional 2007. Dalam: Departemen Kesehatan, penyunting. Jakarta: Departemen Kesehatan; 2008.

3. Lozoff B, Smith JB, Clark KM, Perales CG, Rivera F, Castillo $\mathrm{M}$. Home Intervention improves cognitive and socialemotional scores in iron-deficient anemic infants. Pediatrics 2010;126:e884-e94.

4. Algarín C, Nelson C, Peirano P, Westerlund A, Reyes S, Lozoff B. Iron-deficiency anemia in infancy and poorer cognitive inhibitory control at age 10 years. Dev Med Child Neurol 2013;55:453-8.

5. King FS, Burgess A. Starting Other Food. Nutrition for Developing Countries. New York: Oxford University Press;1993.h.123-40.

6. Rattehallia D, Pickarda L, Tselepisb C, Sharmac N, Iqbal TH. Iron deficiency without anaemia : Do not wait for the haemoglobin to drop? Health Policy and Technology 2013;2:45-58.
7. Congdon EL, Westerlund A, Algarin CR, D P, Peirano, Gregas $\mathrm{M}$, dkk. Iron deficiency in infancy is associated with altered neural correlates of recognition memory at 10 years. Pediatrics. 2012;160:1027-33.

8. Cercamondi CI, Egli IM, Mitchikpe E, Tossou F, Hessou J, Zeder C, dkk. Iron bioavailability from a lipid-based complementary food fortificant mixed with millet porridge can be optimized by adding phytase and ascorbic acid but not by using a mixture of ferrous sulfate and sodium iron EDTA. J Nutr 2013:1-7.

9. Troesch B,Egli I, Zeder C, Hurrell RF, de Pee S, Zimmermann MB. Optimization of a phytase-containing micronutrient powder with low amounts of highly bioavailable iron for inhome fortification of complementary foods. Am J Clin Nutr 2009;89:539-44.

10. Torbjorn L,Lonnerdal B, Persson LA, Stenlund H, Tennefors C, Hernell O. Effects of weaning cereals with different phytate contents on hemoglobin, iron stores, and serum zinc: a randomized intervention in infants from 6 to 12 months of age. Am J Clin Nutr 2003;78:168-75.

11. Dogra N. Preventing Iron-deficiency anemia in children in developing countries - why it is necessary and how it must be approached. The Meducator 2012;1:1-17.

12. Murray R, Granner D, Rodwell V. Harper's illustrated biochemistry. Diakses pada 23 September 2016. Didapat dari: http://www.accesemedicine.com.

13. Victora CG, Onis M, Hallal PC, Blossner M. Worldwide Timing of Growth Faltering: Revisiting Implications for Interventions. Pediatrics 2010;125:e473-80.

14. Lozzof B, Beard J, James C, Barbara F, Michael G, Timothy S. Long-lasting neural and behavioral effects of iron deficiency in infancy. Nutr Ref 2006;64:S34-91. 